https://doi.org/10.22319/rmcp.v11i1.4913

Article

\title{
Growth dynamics and senescence of digit grass as a response to several
} canopy heights

José Dantas Gusmão Filho ${ }^{\mathrm{a}^{*}}$

Daniela Deitos Fries ${ }^{b}$

Braulio Maia de Lana Sousa ${ }^{c}$

Jailson Lara Fagundes ${ }^{c}$

Alfredo Acosta Backes ${ }^{c}$

Daniel Lucas Santos Dias ${ }^{\mathrm{d}}$

Sarita Socorro Campos Pinheiro ${ }^{\text {e }}$

Fábio Andrade Teixeira ${ }^{b}$

a Instituto Federal de Educação, Ciência e Tecnologia de Sergipe - Rodovia Juscelino Kubitschek, s/n - Zona Rural, Nossa Senhora da Glória - SE, 49680-000.

${ }^{\mathrm{b}}$ Universidade Estadual do Sudoeste da Bahia, Bahia, Brasil.

${ }^{\mathrm{c}}$ Universidade Federal de Sergipe, São Cristovão, Sergipe, Brasil.

${ }^{\mathrm{d}}$ Universidade Estadual de Feira de Santana, Bahia, Brasil.

e Instituto Federal de Educação, Ciencia e Tecnologia de Sergipe. São Cristovão, Sergipe, Brasil.

*Corresponding author: dantas.zoot@hotmail.com 


\begin{abstract}
:
The purpose of this study was to examine the growth and senescence dynamics of Digitaria eriantha $\mathrm{cv}$. Survenola as a response to several canopy heights $(25,35,45$, and $55 \mathrm{~cm})$ of harvests in two seasons of the year (rainy and dry). The experiment was established at the Federal University of Sergipe, in São Cristóvão - SE, Brazil, from 03/26/2015 to 03/28/2016, under a randomized-complete-block design with four replicates. Plots were irrigated, and upon reaching the pre-established canopy heights, they were cut to a $10 \mathrm{~cm}$-residual height. Increasing canopy heights in the dry season led to lower tiller density, for basal and aerial tillers. However, irrespective of tiller type and season, this variable increased after the rest period. Light interception rose with canopy heights $(P<0.05)$ in the dry period and it showed a quadratic response in the rainy season. Greater canopy heights led to a higher $(P<0.05)$ daily leaf senescence rates and daily stem growth rates. Regardless of the season, the total accumulation and net herbage accumulation rates of basal tillers increased as canopy heights did. The greatest canopy height promoted the daily stem production, whereas the lowest height did not allow the grass to express its production potential. The defoliation-height range of 35 to $45 \mathrm{~cm}$ is the most recommended, as it favors the control of stem growth and leaf senescence.
\end{abstract}

Key words: Forage accumulation, Digitaria eriantha cv. Survenola, Light interception, Morphogenesis.

Received: 24/05/2018

Accepted 10/12/2018

\title{
Introduction
}

Digitaria eriantha Steud cv. Survenola, named recently for the standardization of scientific writing $^{(1)}$, was once known as Digitaria umfolozi and is popularly identified in Brazil as 'faixa-branca' or 'pangolão'. It is a low-fertility hybrid plant obtained from the cross between D. setivalva Stent and D. valida Stent that has a tussock form of growth and is propagated via stolons. It is somewhat tolerant to low-rainfall periods by reason of its ability to capture dew, that condense together forming water droplets. The plant has a high regrowth capacity, which favors its use for grazing and harvesting ${ }^{(2)}$. It is also the most largely used grass species 
in northeast Brazil, notably in the states of Sergipe and Bahia, mainly because of its persistence in the soil and climatic conditions of that region, which has aroused the interest of producers, however, information on the production of this forage plant is still incipient, and the existing results often originate from regions of different environmental conditions ${ }^{(3)}$.

Net herbage accumulation in a pasture is the result of the balance between growth, senescence, and death of tissues - which are a consequence of the growth of new structures $^{(4)}$ like leaves and stems on individual tillers - and of the number of existing tillers (density), associated with tillering patterns (appearance, mortality, and survival) ${ }^{(5)}$. However, other factors such as the amount and quality of light, temperature, water, and nutrients available in the local environment and the management strategy adopted interfere with photosynthesis and with the growth and senescence dynamics of a pasture ${ }^{(6)}$.

Increases in forage mass influence the leaf area index (LAI) and consequently light interception. Canopy height can be used as an indicator of the right time for defoliation, since LAIs above the 'critical limit' - when the canopy intercepts $95 \%$ of the incident light favor stem and senescent-material accumulation ${ }^{(7)}$. However, adopting a fixed or predetermined rest period for a grass species is not an effective management strategy to monitor the pasture growth and structure, given the physical and structural alterations the plant undergoes throughout the year.

In view of the above considerations, the present study was proposed to evaluate the herbageaccumulation dynamics of Digitaria eriantha cv. Survenola subjected to different canopy heights at two seasons of the year (rainy and dry).

\section{Material and methods}

The study was conducted in the Forage Plants Section of the Federal University of Sergipe (UFS), located in the municipality of São Cristóvão - SE, Brazil (10 55'53.7" S, longitude $37^{\circ} 06^{\prime} 18.8^{\prime \prime} \mathrm{W}, 5 \mathrm{~m}$ asl). According to the Köppen classification, the climate in the region is a tropical Awa type. The average annual precipitation, temperature, and air relative humidity in São Cristóvão are $1,200 \mathrm{~mm}, 25.5^{\circ} \mathrm{C}$, and $75 \%$, respectively ${ }^{(8)}$.

The National Institute of Meteorology (Instituto Nacional de Meteorologia) delivered the climatic data recorded during this study (Figures 1 and 2), where rainy and dry seasons are shown. 
Figure 1. Precipitation, potential evapotranspiration and average, maximum and minimum temperatures during the experimental period $^{(9)}$

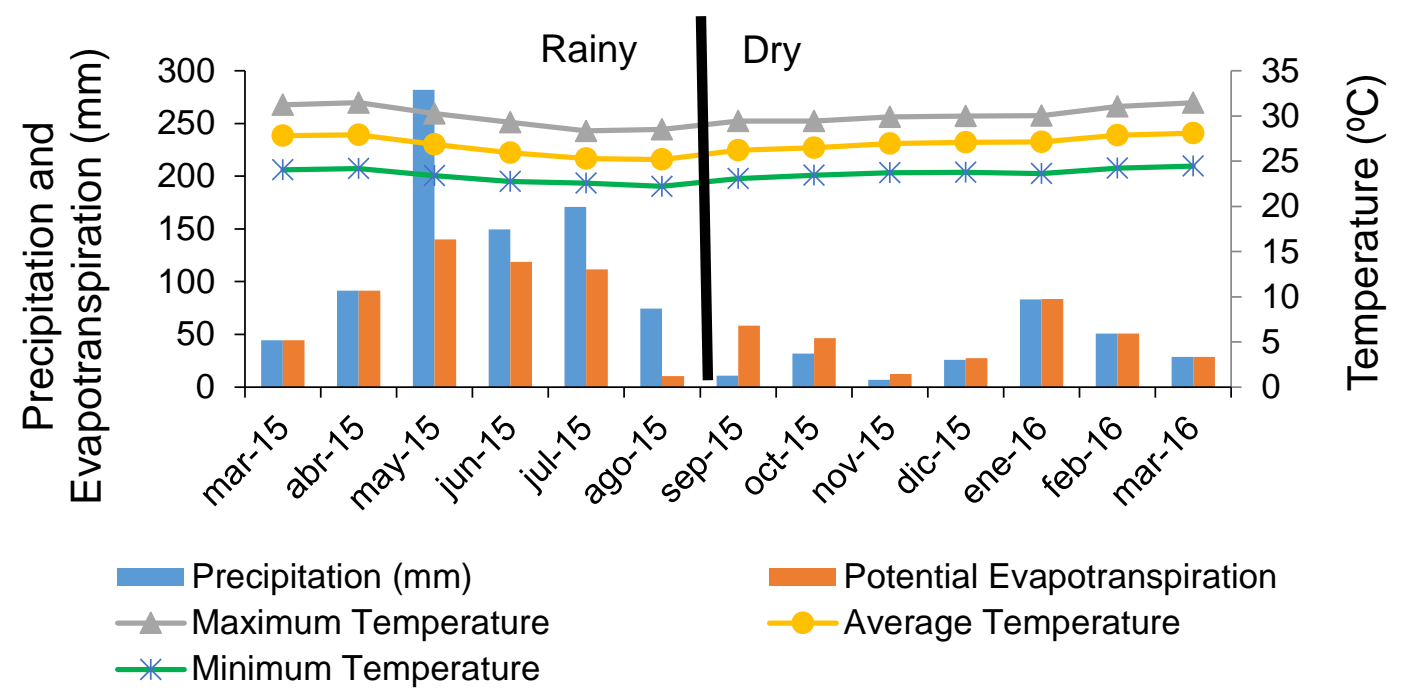

Figure 2. Global radiation $\left(\mathrm{Kj} \mathrm{m}^{2}\right)$ and relative humidity of the air during the experimental $\operatorname{period}^{(9)}$

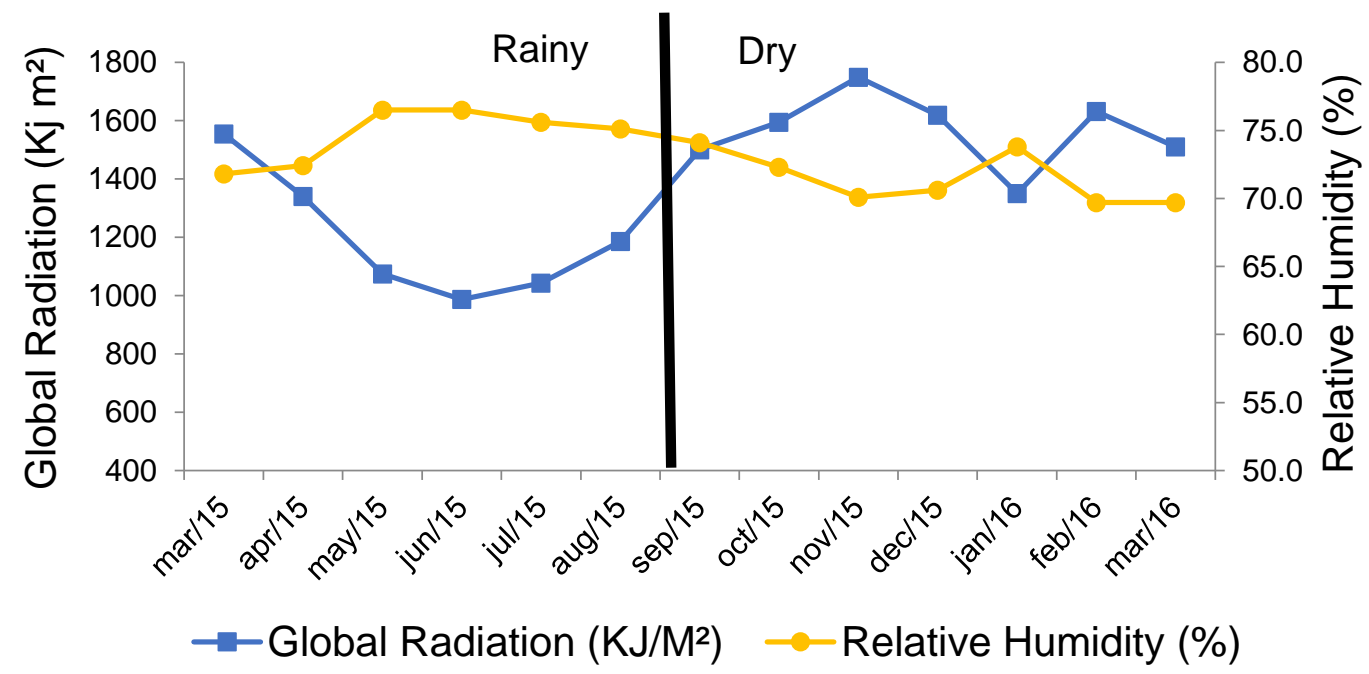

The soil in the experimental area was classified as a Quartzipsamment of clayey texture ${ }^{(10)}$ with a flat relief. Before the experiment was established soil samples with a soil auger from three areas in each plot, at the 0-20 cm layer, and mixed to generate a composite sample. Subsequently, these were sent to the Technological and Research Institute of Sergipe State (Instituto Tecnológico e de Pesquisas do Estado de Sergipe - ITPS) for an analysis of chemical and particle-size properties that revealed the following composition: organic 
matter $=10.6 \mathrm{~g} \cdot \mathrm{dm}^{-3} ; \mathrm{pH}$ in $\mathrm{H}_{2} \mathrm{O}=6.15 ; \mathrm{P}=45.4 \mathrm{mg} \cdot \mathrm{dm}^{-3} ; \mathrm{Na}=0.053 \mathrm{cmolc} \cdot \mathrm{dm}^{-3} ; \mathrm{Ca}=3.78$ cmolc. $\mathrm{dm}^{-3} ; \mathrm{Mg}=1.925 \mathrm{cmolc} . \mathrm{dm}^{-3} ; \mathrm{Al}=0.08 \mathrm{cmolc} . \mathrm{dm}^{-3} ; \mathrm{H}+\mathrm{Al}=0.67 \mathrm{cmolc} . \mathrm{dm}^{-3} ;$ sum of bases $=5.77 \mathrm{cmolc} . \mathrm{dm}^{-3} ; \mathrm{CEC}=6.44 \mathrm{cmolc} . \mathrm{dm}^{-3}$; base saturation $=89.60 \%$, and clay content $9.97 \%$.

According to the results of the soil analysis and in conformity with the recommendations of the Soil Fertility Committee of Minas Gerais State (Comissão de Fertilidade do Solo do Estado de Minas Gerais), no liming was required, since the base saturation content of the soil was $89.6 \%$. However, maintenance fertilization was necessary, and so $200 \mathrm{~kg} \mathrm{ha}^{-1} \mathrm{~K} 2 \mathrm{O}$ in the form of potassium chloride were applied, split in three fractions ${ }^{(11)}$.

During the experimental period, fertilization was performed using $300 \mathrm{~kg} \mathrm{~N} \mathrm{ha}^{-1} \mathrm{yr}^{-1}$ in the form of ammonium sulfate. Because the harvest intervals depended on the time the plants reached the target canopy heights were imposed as treatments, different quantities of nitrogen fertilizer were applied after each harvest.

The grass was established in a total area of $90 \mathrm{~m}^{2}$ in June 2014. The area was divided into sixteen $5.2 \mathrm{~m}^{-2}$-experimental plots. In March 2015, a uniformity cut was made in all plots at $10 \mathrm{~cm}$-stubble to start the study. Evaluations began on 03/26/2015 and ended on 03/28/2016, totaling $368 \mathrm{~d}$ of experimental period. Plots were irrigated with $5 \mathrm{~mm}$ of water the periods of water stress each two days due to the soil low water-retention capacity and the need for improving fertilizer utilization and maximizing herbage growth.

Treatments consisted of four canopy heights $(25,35,45$, and $55 \mathrm{~cm})$ of harvest evaluated at two times of the year: rainy (March 26 to September 20, 2015), and dry seasons (September 21 to March 20,2016). After every evaluation finished, were clipped the plants in all the experimental plots to a $10 \mathrm{~cm}$ of residual herbage. A randomized-complete-block experimental design was adopted, with four replicates, with 16 experimental units.

Canopy height was measured twice weekly, at five points per experimental unit, using a centimeter-graduated ruler ${ }^{(12)}$. Whenever the canopies reached the pre-established heights, was monitored the rest period (PD) (time required for the canopy to reach the established heights), their leaf area index and light interception using a SunScan ${ }^{\circledR}$ canopy analyzer (Delta Devices Ltd., Cambridge, United Kingdom) at three random points per experimental unit (plots). Evaluations corresponded to a reading performed above the canopy and another at the soil level (below the canopy).

The forage accumulation dynamics was evaluated weekly in five basal and five aerial tillers randomly selected and marked (after emergence) per experimental unit measuring the elongation of leaf blades and stems and senescence of leaf blades. On the last day of each evaluation, all marked tillers were cut at the soil level (basal tillers) or at the insertion point (aerial tillers), wrapped in a plastic bag, and immediately transported to a cold room to minimize moisture losses. With these data leaf and stem elongation rates and the leaf 
senescence rate $\left(\mathrm{cm}\right.$ tillers ${ }^{-1}$ day $\left.^{-1}\right)$ were estimated the, used to calculate the forage accumulation rate ${ }^{(13)}$.

Then, were dried the basal and aerial tillers in a forced-air oven at $65^{\circ} \mathrm{C}$ for $72 \mathrm{~h}$ and weighted them. Were calculated a length-mass conversion factor dividing the mass of each component by its respective growth, which was used to transform all field readings from $\mathrm{cm}$ tiller ${ }^{-1} \mathrm{~d}^{-1}$ into $\mathrm{mg}_{\text {tiller }}^{-1} \mathrm{~d}^{-1}$. Finally, were multiplied these values by their respective tiller density in each experimental unit in order to compute the forage dry matter (DM) in $\mathrm{kg} \mathrm{ha}^{-1} \mathrm{~d}^{-1}$.

Were assessed the live tillers density using $0.25-\mathrm{m}^{2}$-metal-frame placed at random per experimental unit, always pre-harvest. Thus, the values for leaf and stem elongation rates and leaf senescence rate were transformed into leaf and stem growth rates and leaf senescence rate $\left(\mathrm{kg} \mathrm{ha}^{-1} \mathrm{~d}^{-1}\right.$ dry matter), respectively, for basal and aerial tillers. The sum of leaf growth and stem growth resulted in the total growth rate, whereas forage accumulation rate was calculated as the difference between total growth rate and leaf senescence rate ${ }^{(14)}$.

The variance analyzes were performed, considering a randomized block design with four replicates, and orthogonal decomposition of the sum of treatment squares into linear, quadratic, and cubic effects to probe the best fit of the model. The significance of effects was analyzed by the $\mathrm{F}$ test, at $\alpha=0.05$, using the Computational Package Statistical Analysis System (SAS), version 9.0.

\section{Results and discussion}

Tiller density (TD) decreased linearly $(P<0.05)$ for basal (Figure 3A) and aerial (Figure 3B) tillers in the dry season as the canopy heights increased. The same was not influenced $(P>0.05)$ during the rainy season. 
Figure 3. Tiller density (TD, A and B), rest period (RP; C) and light interception (LI; D) of basal (A) and aerial (B) tillers of digitgrass as a function of canopy heights during the rainy ( $\bullet$ ) and dry

(०) seasons
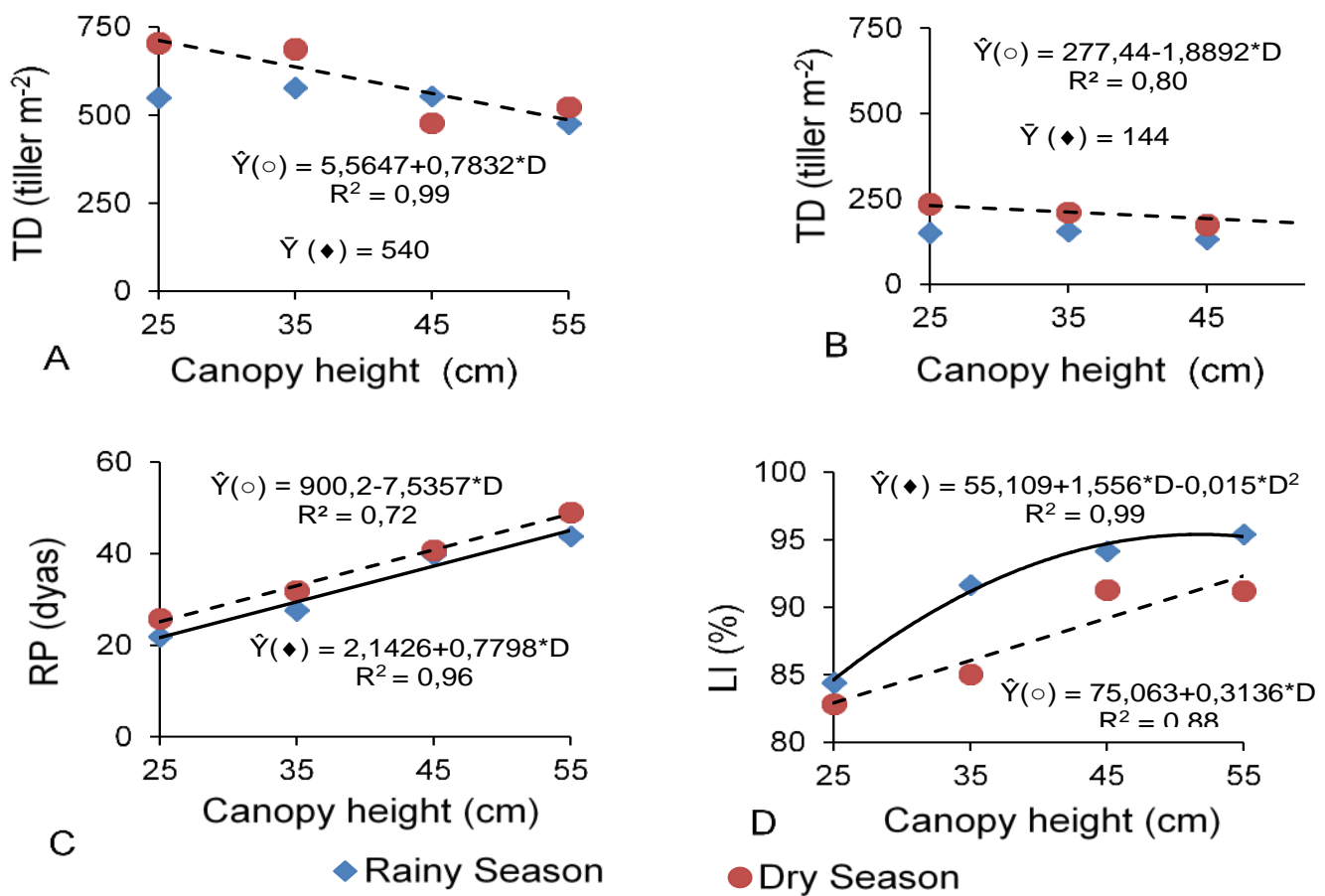

The rest period (Figure 3C) of the basal tillers, in the two seasons; and light interception (LI) (Figure 3D) in the dry period increased linearly $(P<0.05)$ with the canopy heights. In the rainy season, this last variable responded quadratically $(P<0.05)$ with a maximum LI value of $95.5 \%$ at the canopy height of $55 \mathrm{~cm}$ (Figure 3D).

The reduction in the density of Basal (Figure 3A) and aerial (Figure 3B) tillers in the dry season, as the canopy heights increased can be explained by the longer rest period (Figure 3C); i.e., during the time to reach the target canopy heights, leaf production and stem elongation enlarged, which initially contributed to increasing light interception (Figure 3D), but ultimately reducing the incidence of light under the canopy. Reduced incidence of light at the base of the canopy caused the decrease of tiller density, as the activation of basal and axillary buds for the production of new tillers was inhibited ${ }^{(15)}$, as the rest time was longer for the greater canopy heights. In an experiment with Marandu Palisadegrass, longer harvest intervals negatively affected tiller densities, which was possibly due to the amount and quality of light reaching the canopy ${ }^{(16)}$. The reduction of light at the base of the lawn with increasing pasture height, influences the reduction of the population density of tillers ${ }^{(17)}$.

In the dry period, the intervals between harvests for the canopy to reach the pre-defined heights was on average $11.5 \%$ longer than in the rainy period. Even though the plots were irrigated, evapotranspiration (Figure 1) and limited soil water retention capacity may explain 
these results; i.e., the amount of water was not sufficient to provide the ideal plant-growth conditions. In the rainy season, the climatic conditions (e.g., higher precipitation (Figure 1) and solar radiation of $1197.3 \mathrm{kj} \mathrm{m}^{2}$ (Figure 2) positively influenced plant growth. These results are likely due to the higher photosynthesis rates, which may culminate in elevated production of photo assimilates, thereby providing better conditions for plant growth. In an evaluation of the structural traits of Tanzania grass, more leaves had to be produced for the canopy to reach 95 or $97 \%$ of LI, so grass plants could intercept more light and required longer rest periods ${ }^{(15)}$. The longer the canopy needs to attain a pre-established height, the larger the forage accumulation will be, especially under favorable conditions, such as higher precipitation, temperature, and light. However, this larger forage mass may result from the growth of stem and dead material, since leaf production increase is stabilized and stem growth and senescence processes are accelerated ${ }^{(7)}$.

Leaf growth rate (LGR) in basal (Figure 4A) and aerial (Figure 4B) tillers was not influenced $(P>0.05)$ by the increasing canopy heights during the rainy and dry seasons. However, the leaf senescence rate of basal (Figure 4C) and aerial (Figure 4D) tillers, and the stem growth rate (SGR) of basal (Figure 4E) and aerial (Figure 4F) tillers in both seasons increased linearly $(P<0.05)$ as canopy heights were greater.

As a result, because of its longer rest period (Figure 3C), the highest canopy height $(55 \mathrm{~cm})$ would reduce the grass productivity, since no record higher daily growth rates under this treatment. The results for leaf senescence rate (Figures $4 \mathrm{C}$ and $\mathrm{D}$ ) may be a consequence of the longer rest periods (Figure 3C), which led the leaves to reach their maximum lifespan and increase senescence rate. Higher canopy heights granted further plant development, as a consequence, more leaves completed their lifespan and senescent tissue accumulated ${ }^{(18)}$.

The senescence rates of basal (Figure 4C) and aerial (Figure 4D) tillers while raining were $43 \%$ and $26 \%$ higher, on average, than in the dry season, respectively. This is explained by the higher rainfall (Figure 1) in the wet period. Solar radiation and temperature in this last season (Figure 2) averaged $1197.3 \mathrm{kj} \mathrm{m}^{2}$ and $27.8{ }^{\circ} \mathrm{C}$, in that order. Despite the irrigation during the months with sparser precipitation, evapotranspiration (Figure 1) might have influenced these results. 
Figura 4. Leaf growth (LGR, A and B), leaf senescence (LSR, C and D) and stem growth rates (SGR, E and F) of basal ( $\mathrm{A}, \mathrm{C}$ and $\mathrm{E})$ and aerial $(\mathrm{B}, \mathrm{D}$ and $\mathrm{F})$ tillers of digitgrass as a function of canopy heights during the rainy $(\bullet)$ and dry $(\circ)$ seasons
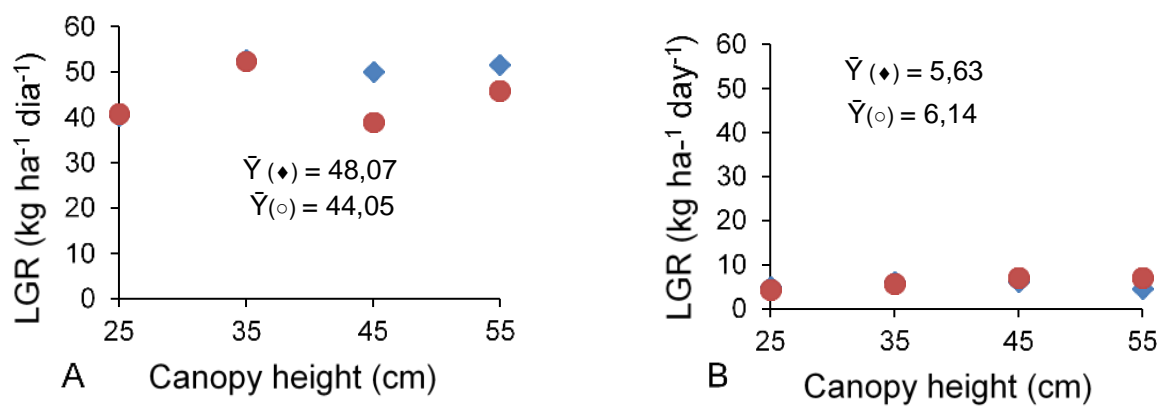

A Canopy height $(\mathrm{cm})$
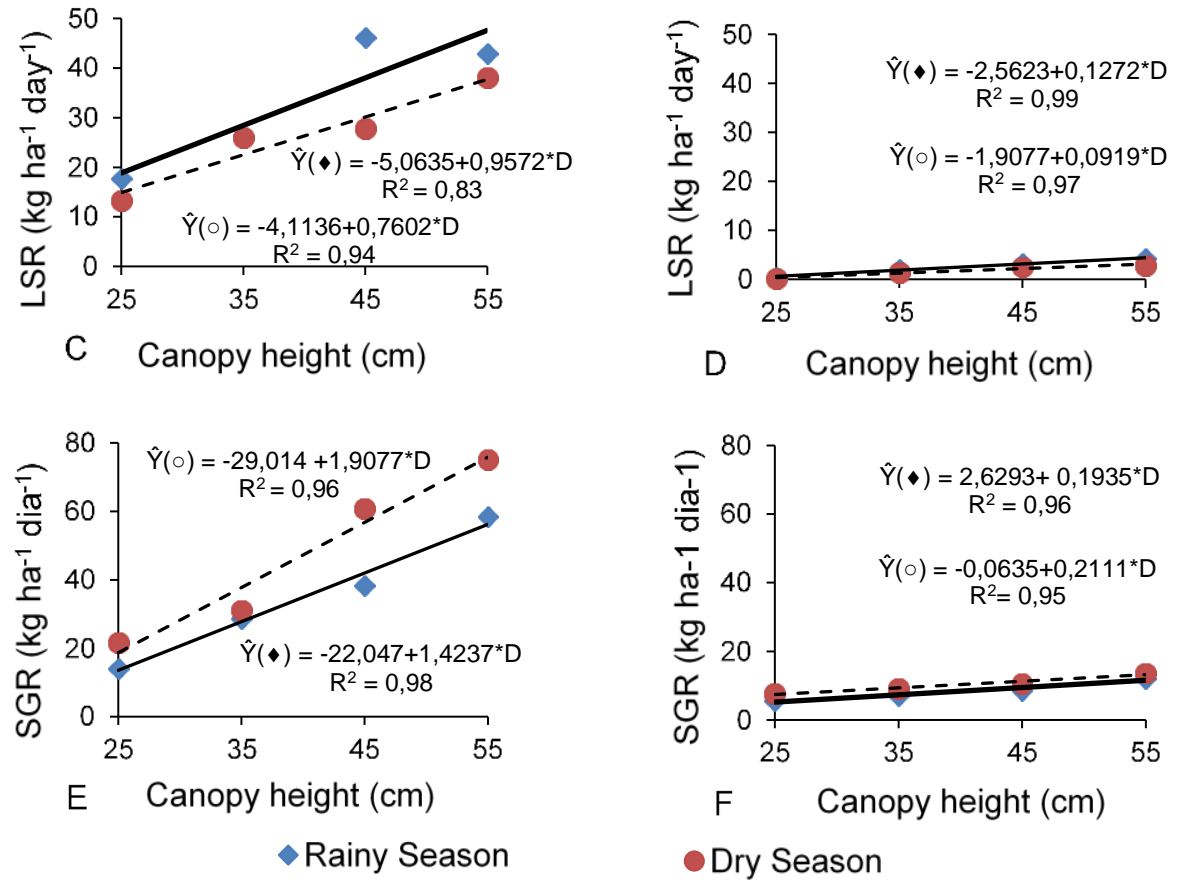

- Dry Season

The increasing canopy height provided a longer rest period (Figure 3C), and favored the stem and dead material to build up, which was likely due to the shading of basal leaves. At the greatest canopy heights, stem elongation might occur as an attempt to rise the younger leaves in the upper stratum of the pasture, where canopy receives more photosynthetically active radiation. Increasing stem elongation and growth rates should reduce the pasture quality, because stems are the most fibrous fraction of forage, restricting its digestibility ${ }^{(15)}$. The shading of leaves at the base of the canopy may reduce their photosynthetic efficiency and tiller density in a mechanism known as population size/density compensation, in addition to elevating the accumulation of old tillers, which have leaf appearance and elongation rates reduced and senescence rate increased ${ }^{(19)}$. 
Total growth rate (TGR) (Figure 5A) of basal tillers rose linearly $(P<0.05)$ at both seasons, but the net herbage accumulation rate (NHAR) (Figure $5 \mathrm{C}$ ) just did it during the dry season $(P<0.05)$ as canopy heights were greater. About aerial tillers, the TGR (Figure 5B) improved during the dry season, but remained with no change during the rainy season.

Figura 5. Total growth rate (TGR; A and B) and net herbage accumulation rate (NHAR; C and $\mathrm{D})$ in basal (A and C) and aerial (B and D) tillers of digitgrass as a function of defoliation heights during the rainy $(\bullet)$ and dry $(\circ)$ seasons
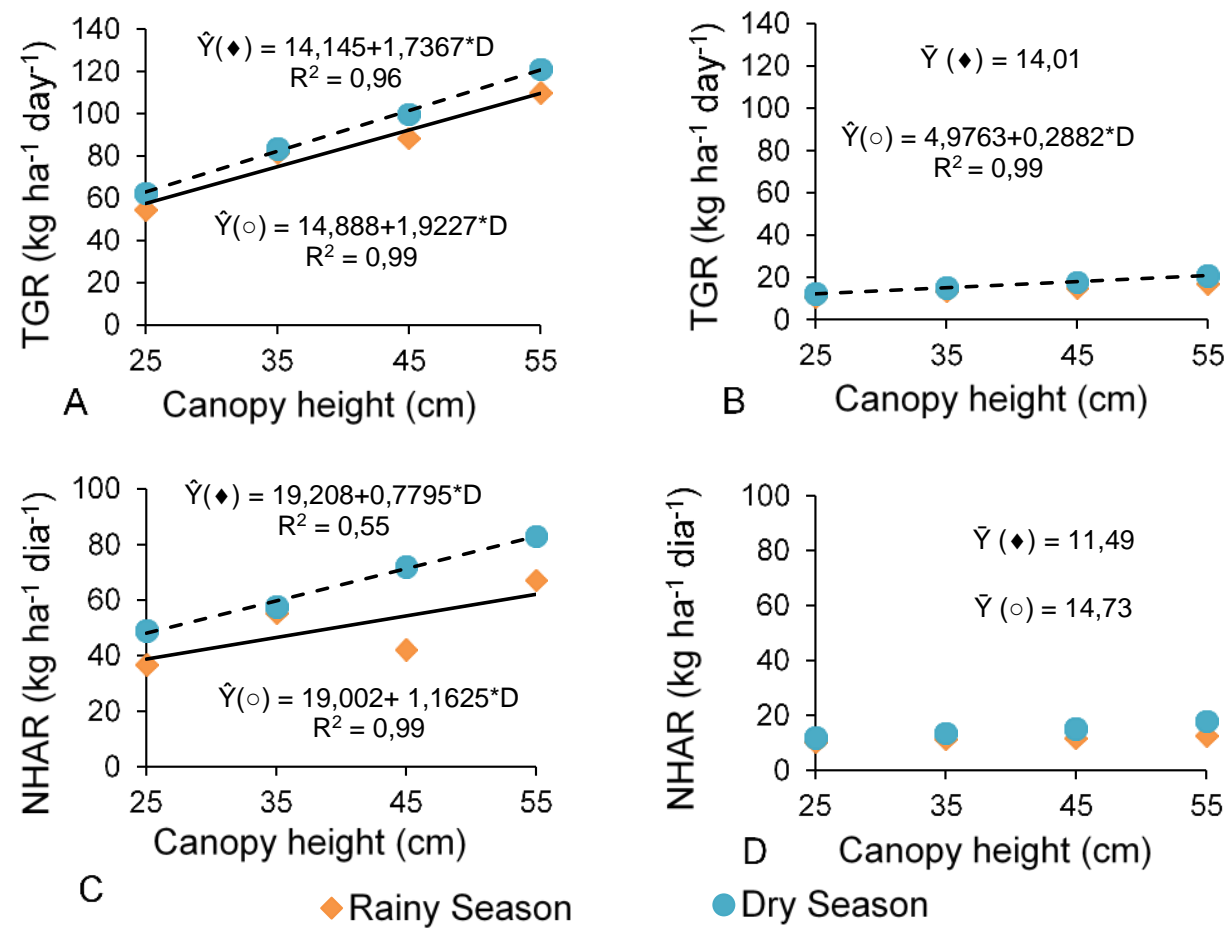

NHAR (Figure 5D) did not change at the two seasons $(P>0.05)$ because of the canopy heights. The population density of basal and aerial tillers (Figures $3 \mathrm{~A}$ and $3 \mathrm{~B}$ ), leaf senescence rate (Figures 4C and 4D) and stem growth rate (Figures 4E and 4F) influenced, at different magnitudes, the TGR and NHAR of basal and aerial tillers during the dry and rainy seasons.

Because the canopy heights did not influence leaf growth rate (Figures 4A and 4B), then, the stem growth rate (Figure $4 \mathrm{E}$ and $4 \mathrm{~F}$ ) and hence possibly the tiller size:density ratio ${ }^{(17)}$ may explain the higher total growth rate (Figures 5A and B) and consequently NHAR (Figure 5C) as canopy heights increased. Results probed that the density of basal (Figure 4A) and aerial (Figure 4B) tillers in the dry season declined, as the canopy heights were greater; whereas 
was did not find any influence in the rainy season. However, the increasing canopy height may require heavier tillers to support its structure, which influenced the stem growth (Figures 4E and $4 \mathrm{~F}$ ) and senescence rates (Figures 4C and 4D). Other authors found that seasons of the year and canopy heights also modified the tiller size:density ratio: Decreasing tiller densities are compensated by an increase in tiller weight, which results from higher stemand leaf-elongation rates ${ }^{(20)}$. They observed that seasonal variations influenced the results. In an study with Tanzania grass subjected to three grazing intervals (90, 95, and $100 \% \mathrm{LI}$ ) and two defoliation intensities ( 25 and $50 \mathrm{~cm}$ height), long rest periods caused changes in the canopy structure, with greater contribution of stem and dead material ${ }^{(21)}$. In this experiment, the increasing canopy heights elicited responses similar to those reported in this last study, with larger proportions of stem and greater senescence.

At the lowest canopy height $(25 \mathrm{~cm})$, results indicated an increase in the density of basal (Figure 3A) and aerial (Figure 3B) tillers during the dry season. For basal and aerial tillers in both seasons, however, there was a decrease in the rest period (Figure 3C), light interception percentage (Figure 3D), leaf senescence rate (Figures 4C and 4D), and stem growth rate (Figures 4E and 4F). On the other hand, TGR (Figures 5A and 5B) for basal tillers in the two seasons and aerial tillers in the dry season was lower at the 25-cm-canopy height. The same was true for NHAR (Figure 5C) of basal tillers in both seasons. Based on these results, it is suggested that, at the lowest height, senescence and stem elongation were lessened, implying a better forage nutritional quality. Nevertheless, higher defoliation frequencies, with shorter rest periods, may deplete the energy reserve of grass plants for canopy growth and, at the end, reduce the persistence of this grass over time. The greatest defoliation height $(55 \mathrm{~cm})$ provided the lowest tiller density (Figures $3 \mathrm{~A}$ and $3 \mathrm{~B}$ ) for basal and aerial tillers in the dry season; and the highest leaf senescence rate (Figures 4C and 4D) and stem growth rate (Figures $4 \mathrm{E}$ and $4 \mathrm{~F}$ ) for basal and aerial tillers in the two periods, which may negatively influence the herbage digestibility. A longer rest period may bring about an increase in stem and senescent-material growth rates, which may reduce the pasture quality ${ }^{(15)}$. Therefore, letting the canopy to reach between 35 and $45 \mathrm{~cm}$ can benefit herbage accumulation as well as provide better quality to digit grass, and ultimately improving its productivity. Depending on the time of the year and growth conditions, a shorter rest period with lower defoliation heights may lead to yield losses, whereas longer rest periods may induce nutritional and quantity losses. Moreover, both cases can result in pasture degradation ${ }^{(7)}$.

As previously discussed, the tiller size:density ratio influenced the results; stem elongation was higher possibly because the rest period to reach the greater canopy heights was longer. Other research probed that the weight of tillers in the vegetative stage is lower than in the reproductive stage for Brachiaria decumbens, which also bore inflorescences ${ }^{(22)}$. The same authors reported that taller plants had heavier vegetative tillers, but a lower tiller density. These findings can explain the present results, where the increasing canopy heights provided an increase in TGR and NHAR. In the dry season, the vegetative tillers changed to a 
reproductive stage that resulted in higher stem growth rates. In an evaluation of the nutritional value of tillers from Brachiaria decumbens cv. Basilisk plants, researchers found a greater stem elongation rate when tillers progressed from the vegetative to the reproductive state, contributing to a lower leaf:stem ratio ${ }^{(23)}$.

\section{Conclusions and implications}

Digit grass should be managed in a defoliation-height interval of 35 to $45 \mathrm{~cm}$, because when defoliated above this range, it reaches a greater accumulation of forage, to the detriment of greater accumulation of stem and dead material. Further studies should be undertaken focusing on the residual height with animals involved in the evaluation procedures, under different environmental conditions.

\section{Acknowledgments}

The authors thank the department of Animal Science of the Universidade Federal de Sergipe, the Animal Science Graduate Program of Universidade Estadual do Sudoeste da Bahia, and the Instituto Federal de Educação, Ciência e Técnologia de Sergipe, Brazil for the support provided for the development of this research. This study was financed in part by the Coordenação de Aperfeiçoamento de Pessoal de Nível Superior - Brasil (CAPES) - Finance

Code 001, and also Conselho Nacional de Desenvolvimento Científico e Tecnológico (CNPq) and Fundação de Apoio à Pesquisa e à Inovação Tecnológica do Estado de Sergipe (FAPITEC). 


\section{Literature cited:}

1. Cook BG, Schultze-kraft R. Botanical name changes-nuisance or a quest for precision?. Trop Gras-For Trop 2015;3(1):34-40.

2. Navarro L, Rodríguez I, Goncález S, Torres A. Umfolozi o Pangola Peluda: Um pasto que Comieza a ser Cutivado.In: Pérez E, Rengifo-AC, Santos AR. Revide dif de tecn agríc, pec, pesq y acuí. Aragua, Venezuela: INIA Divulga; 2005:29-32.

3. Souza LJN, Santos DBO, Fagundes JL, Sousa BML, Backes AA, Oliveira-Junior LFG, Santos ADF, Moreira AL. Morfogênese do capim faixa-branca submetido à adubação nitrogenada. Bol Ind Ani 2016; 73(4):281-289.

4. Hodgson J. Grazing management: Science into practice. New York: John Wiley and Sons; 1990.

5. Bircham JS, Hodgson J. The influence of sward condition on rates of herbage growth and senescence in mixed swards under continuous stocking management. Grass Forage Sci 1983;38(4):323-331.

6. Santos MER, Fonseca DM, Gomes VM, Gomide CAM, Nascimento-Junior D, Queiroz DS. Capim-braquiária sob lotação contínua e com altura única ou variável durante as estações do ano: morfogênese e dinâmica de tecidos. Rev Bras Zootec 2011;40(11):2323-2331.

7. Pedreira BC, Pedreira CGS, Da Silva SC. Acúmulo de forragem durante a rebrotação de capim-xaraés submetido a três estratégias de desfolhação. Rev Bras Zootec 2009;38(4): 618-625.

8. Melo AS, Netto AOA, Neto JD, Brito MEB, Viégas PRA, Magalhaes LTS, Fernandes PD. Desenvolvimento vegetativo, rendimento da fruta e otimização do abacaxizeiro cv. Pérola em diferentes níveis de irrigação. Ciênc Rural 2006;36(1):93-98.

9. INMET. Instituto Nacional de Meteorologia - Banco de Dados Meteorológico para Ensino e Pesquisa - BDMEP. Brasília. Disponível em: $<$ http://www. inmet.gov.br/portal/index.php?r=bdmep/bdmep. Consultado 20 Ene, 2016.

10. EMBRAPA. Centro Nacional de Pesquisa de Solos (Rio de Janeiro, RJ). Sistema brasileiro de classificação de solos. Brasília: Embrapa Produção de Informação; Rio de Janeiro: Embrapa Solos 1999.

11. Ribeiro AC, Guimarães PTG, Alvarez VVH. (Ed.). Recomendação para o uso de corretivos e fertilizantes em Minas Gerais: 5. Aproximação. Viçosa: Comissão de Fertilidade do Solo do Estado de Minas Gerais. Viçosa,Brasil: UFV, 1999. 
12. Pena KS, Junior DN, Silva SC, Euclides VPB, Zanine AM. Características morfogênicas, estruturais e acúmulo de forragem do capim-tanzânia submetido a duas alturas e três intervalos de corte. Rev Bras Zootec 2009;38(11):2127-2136.

13. Lemaire E, Chapman D. Tissue flows in grazed plant communities. In: Hodgson I, Illius AW, editors. The ecology and management of grazing systems. Wallingford: CAB International; 1996:3-36.

14. Sousa BML, Nascimento-Júnior D, Monteiro HCF, Da-Silva SC, Vilela HH, Silveira MCT, Rodrigues CS, Sbrissia AF. Dynamics of forage accumulation in Elephant grass subjected to rotational grazing intensities. Rev Bras Zootec 2013;42(9):629-638.

15. Cutrim Junior JAA, Cândido MJD, Valente, BSM, Carneiro MSS, Carneiro HAV. Características estruturais do dossel de capim tanzânia submetido a três frequências de desfolhação e dois resíduos pós pastejo. Rev Bras Zootec 2011; 40(3):489-497.

16. Difante GS, Junior DN, Da Silva SC, Euclides VPB, Montagner DB, Da Silveira MCT, Pena KS. Características morfogênicas e estruturais do capim-marandu submetido a combinações de alturas e intervalos de corte. Rev Bras Zootec 2011;40(5):955-963.

17. Sbrissia AF, Da-Silva SC. Compensação tamanho/densidade populacional de perfilhos em pastos de capim-marandu. Rev Bras Zootecn 2008;37(1):35-47.

18. Santos MER, Fonseca DM, Braz TGS, Silva SP, Gomes VM, Silva GP. Características morfogênicas e estruturais de perfilhos em locais do pasto de capim-braquiária com alturas variáveis. Rev Bras Zootec 2011;40(3):535-542.

19. Paiva AJ, Silva SC, Pereira LET, Caminha FO, Pereira PM, Guarda VDA. Morphogenesis on age categories of tillers in marandu palisadegrass. Sci Agric 2011;68(6):626-631.

20. Paciullo DSC, Campos NR, Gomide CAM, Castro CRT, Tavela RC, Rosiello ROP. Crescimento de capim-braquiária influenciado pelo grau de sombreamento e pela estação do ano. Pesq Agrop Bras 2008;43(7):917-923.

21. Barbosa RA, Nascimento-Júnior D, Vilela HH, Da-Silva SC, Euclides VPB, Sbrissia AF, Sousa BML. Morphogenic and structural characteristics of guinea grass pastures submitted to three frequencies and two defoliation severities. Rev Bras Zootec 2011;40(5):947-957.

22. Santos MER, Fonseca DM, Pimentel RM, Silva GP, Gomes VM, Silva SP. Número e peso de perfilhos no pasto de capim-braquiária sob lotação contínua. Acta Scient Animal Sci 2011;33(2):131-136. 
23. Santos MER, Fonseca DM, Balbino EM, Silva SP, Monnerat JPIS. Valor nutritivo de perfilhos e componentes morfológicos em pastos de capim-braquiária diferidos e adubados com nitrogênio. Rev Bras Zootec 2010;39:1919-1927. 